\title{
POPULATION DYNAMICS AND DISTRIBUTION OF OZIUS TRUNCATUS H. MILNE EDWARDS, 1834 (BRACHYURA, OZIIDAE) ON ECHINODERM REEF, LEIGH MARINE RESERVE, NEW ZEALAND
}

\author{
KALAYARASY SIVAGURU ${ }^{1,3}$ ) and COLIN L. MCLAY ${ }^{2,4}$ ) \\ 1) Department of Biological Sciences, University of Auckland, Auckland, New Zealand \\ 2 ) School of Biological Sciences, Canterbury University, Christchurch, New Zealand
}

\begin{abstract}
Knowledge about the population ecology of predatory crabs from the Pacific Ocean is very limited. Ozius truncatus $\mathrm{H}$. Milne Edwards, 1834 is a relatively large brachyuran crab found on rocky intertidal shores in northern New Zealand. Densities of this crab at Leigh Marine Reserve were as high as about $2 \mathrm{~m}^{-2}$ in summer, but the distribution was very patchy. Juvenile crabs are recruited in late summer and grow to about $15 \mathrm{~mm}$ in carapace length (CL) in one year when they begin to reach sexual maturity. In their second and third years they reach about $25 \mathrm{~mm}$ and $35 \mathrm{~mm}$ CL, respectively. Males and females have a similar average size $(26.9 \mathrm{~mm}$ and $28.1 \mathrm{~mm}$ $\mathrm{CL}$ ) and the sex ratio is $1: 1$. A female living to the maximum age, estimated at $3+\mathrm{yrs}$, could produce three to four annual broods. Crabs were ovigerous from October to February during the two years of the study. Monitoring of tagged crabs shows that they have a high level of site fidelity and limited spatial range. This suggests that any impact of these predators will only be localized.
\end{abstract}

\section{RÉSUMÉ}

La connaissance de l'écologie des populations de crabes prédateurs de l'océan Pacifique est très limitée. Ozius truncatus H. Milne Edwards, 1834 est une relativement grande espèce de crabe vivant sur les fonds rocheux de la zone intertidale au nord de la Nouvelle-Zélande. Les densités de cette espèce dans la réserve marine de Leigh atteignent 2 par $\mathrm{m}^{2}$ en été, mais leur distribution est très irrégulière. Les juvéniles sont recrutés à la fin de l'été et grandissent jusqu'à $15 \mathrm{~mm}$ de longueur (CL) en un an, lorsqu'ils atteignent la maturité sexuelle. Dans leur seconde et troisième année ils atteignent 25 puis $35 \mathrm{~mm}$ (CL). Les males et les femelles sont de tailles similaires $(26,9$ et $28,1 \mathrm{~mm}$ ) avec un sexa ratio de 1 . Une femelle vivant jusqu'à l'âge maximal de trois ans pourra produire trois à quatre pontes, une par an. Les crabes ont

\footnotetext{
3 ) Corresponding author; e-mail: ksivaguru@doc.govt.nz

${ }^{4}$ ) e-mail: colin.mclay@ canterbury.ac.nz 
été ovigères d'octobre à février pendant les deux années de cette étude. Le suivit des crabes marqués montre qu'ils sont fidèles au même site et font des déplacements réduits. Cela suggère que l'impact de ces prédateurs sera seulement localisé.

\section{INTRODUCTION}

Several studies have suggested that crabs have a significant impact on rocky intertidal reefs (Kitching \& Lockwood, 1974; Bertness \& Cunningham, 1981; Menge, 1983; Lubchenco et al., 1984; Lowell, 1986; Hughes, 1989), but this depends upon their numbers and distribution on the shore. Being larger and often more aggressive the prime requirement of these crabs is a refuge where they can hide from each other when the tide is out (Bertness $\&$ Cunningham, 1981). Often very few of these crabs show up in randomly placed quadrats, traditionally used for shore surveys, because their distribution is patchy or they hide in places hard to sample, so it is difficult to assess their importance in rocky shore communities. The impact of predators on the shore depends upon their numbers and prey consumption: i.e., their "numerical" and "functional" responses (Holling, 1966). Each of these responses has several components. The components of the numerical response are recruitment, mortality, and growth, all of which determine mean size and numbers of crabs; the components of the functional response are per capita prey consumption and mobility (foraging area). Taken together, the product numbers $\mathrm{x}$ consumption, gives an estimate of impact. Here we provide estimates of the population size of an oziid crab in northern New Zealand, Ozius truncatus H. Milne Edwards, 1834, its dynamics and mobility, providing a numerical component of predatory impact. The functional component and assessment of the overall impact of $O$. truncatus in the ecosystem will be presented separately (Sivaguru $\&$ McLay, in prep.) (see Sivaguru, 1997 for details of the entire study).

Ozius truncatus is normally found under intertidal boulders and cobbles. It is a generalist predator with dimorphic chelipeds that is capable of eating a wide variety of gastropods (Chilton \& Bull, 1984, 1986; Skilleter \& Anderson, 1986; and Hughes, 1993). Chilton \& Bull (1984) identified a strong, negative correlation between the position of $O$. truncatus and the distribution of gastropods on shores in southern Australia: low abundance of small snails low on the shore corresponded to high densities of reef crabs. They suggested that this pattern could be largely caused by these crabs because they selectively consume small snails (Chilton \& Bull, 1984) and larger snails have a size refuge from predation. The large cheliped is used to open snails and shells of 
the same gastropod species inhabited by hermit crabs (C. L. McLay, unpubl. data) by chipping fragments from around the aperture or, with small shells, by crushing the entire shell. Given their relatively large size, $O$. truncatus could have a significant impact on gastropod and hermit crab populations on rocky New Zealand shores. At our study site in the Leigh Marine Reserve the distribution of $O$. truncatus overlaps with that of several species of gastropods: Nerita melanotragus E. A. Smith, 1884, Diloma aethiops (Gmelin, 1791), Haustrum scobinum (Quoy \& Gaimard, 1833), Lunella smaragda (Gmelin, 1791), Diloma nigerrima (Gmelin, 1791), Haustrum haustorium (Gmelin, 1791), and the hermit crabs (Pagurus novizealandiae (Dana, 1852) and $P$. traversi (Filhol, 1885), Paguridae)) that occupy the empty shells of these gastropods. Both snails and hermit crabs are potential prey items.

No estimates of the density of $O$. truncatus in New Zealand have been attempted, probably because they would only be rarely detected using strict random sampling. Our study is unusual because it involves repeated sampling of the same marked crabs (sampling with replacement). During the course of the study, the same crabs were counted several times from a defined area of the rocky intertidal. Little is known about the abundance of this crab in New Zealand and nothing is known about its population dynamics other than that ovigerous females have been found from October to January, planktonic development includes 4 zoeal stages (Wear, 1968; Wear \& Fielder, 1985), and settlement occurs about 4-6 weeks after hatching (McLay, 1988).

Some aspects of the population dynamics of $O$. truncatus on Echinoderm Reef in the Leigh Marine Reserve, Auckland (fig. 1a) are here described: (1) distribution and abundance on the shore; (2) population size structure, sex ratio, period of recruitment, and (3) the patterns of crab movements.

\section{METHODS}

The study area was a rocky intertidal reef of gently sloping sandstone and mudstone in the Leigh Marine Reserve ( $\left.36^{\circ} 16^{\prime} \mathrm{S} 174^{\circ} 48^{\prime} \mathrm{E}\right)$. Intertidal rock makes up about 38.2 ha (7\% of the Reserve) (Ayling, 1978), but habitat suitable for Ozius truncatus is perhaps only 3-4 ha. The tidal range is approximately $2.2 \mathrm{~m}$ and the climate is warm temperate with mean sea surface temperatures ranging from $13.5^{\circ} \mathrm{C}$ in August to $21^{\circ} \mathrm{C}$ in February (Evans, 1992). The predominant assemblages on the rocky reef have been described by Creese (1988). Initial sampling by random quadrats $\left(4 \mathrm{~m}^{2}\right)$ of Echinoderm Reef resulted in only small numbers of $O$. truncatus being found. A more 
intensive search established patches of boulders where crabs were normally found and so the study site was divided into labelled areas with the results recorded separately for each clump (fig. 1b, c). These were separated by natural discontinuities of unsuitable habitat. From each area the numbers, sizes (measured as carapace length to the nearest $\mathrm{mm}$ ), and sex of every crab found were recorded. Thus our study is a meta-population analysis of fixed sites. Sampling commenced in May 1996, initially using the four clumps that had the highest densities of crabs in the preliminary survey. The numbers of crabs in these clumps declined steadily over the next two months, and in August 1996 the sampling programme was expanded to include all 15 major clumps in the upper-mid intertidal area of Echinoderm Reef. Sampling on this basis continued monthly until July 1998. Inability to move some boulders meant that small crabs $(<10 \mathrm{~mm} \mathrm{CL})$ tend to be under-represented. Newly recruited juveniles are pale pink in colour. Patterns on the carapace start to develop when crabs are approximately $13 \mathrm{~mm} \mathrm{CL}$, and by $20 \mathrm{~mm}$ they are of the same coloration, deep chocolate brown with black fingers, as adult crabs. The number of ovigerous females was recorded at each sample date in order to determine the reproductive period.

To investigate the extent of movements between boulders, crabs were tagged by gluing numbered plastic labels (Hallmark Ltd., Adelaide, Australia). This tagging method was tested with control crabs held in seawater tanks at the Leigh Laboratory and no mortality resulted. Marked rocks were used as reference points to locate each crab and to measure the distance moved between monthly samples. As new crabs were encountered they were tagged in the same fashion at each monthly census from May 1996 to June 1997. During their first year crabs less than $20 \mathrm{~mm}$ CL may have been tagged more than once because of moulting, but this could only influence the picture of apparent movements because population size was estimated by total count.

\section{RESULTS}

\section{Population dynamics}

Our study of Ozius truncatus covered the period May 1996 to July 1998 (table I, figs. 2, 3). Amongst crabs CL $>15 \mathrm{~mm}$ there were no signs of a cohort structure at the beginning of the study in May 1996. With larger sample sizes from July 1996, two groups become evident: one group with CL of about $25 \mathrm{~mm}$ and another group with CL of about $35 \mathrm{~mm}$. These two groups were 

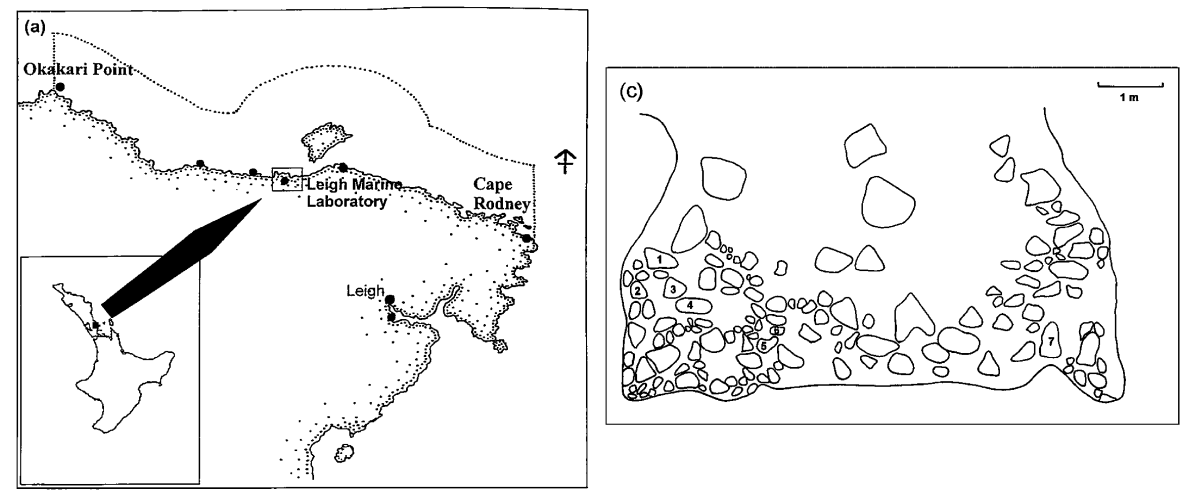

(b)
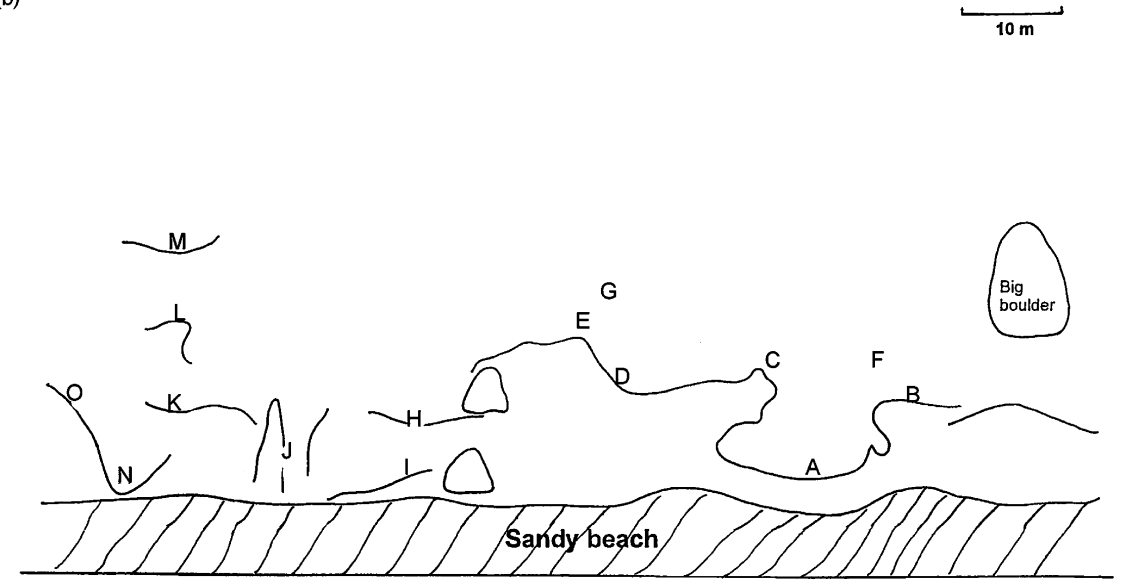

Fig. 1. a, Map of north-eastern New Zealand showing the location of Leigh Marine Reserve and its boundaries (dotted line) with study area indicated by a small box; distribution: 1b, location of marked crab clump sites A-O on Echinoderm Reef (scale bar $=10 \mathrm{~m}$ ); 1c, detailed map of Clump A showing micro-spatial pattern, traced from a photograph, showing location of crabs under stones (1-7) in April 1996 (scale bar =1 m).

evident in August 1996 so the smaller group may be a cohort recruited in the preceding summer, 1996-97, while the larger group may be a cohort from the summer previous to that, 1995-96. These two cohorts remained evident in some months following August 1996. By September 1997 the 1996-97 cohort became the $35 \mathrm{~mm}$ CL group and these continued to increase in size through the 1997-98 summer but dwindled in numbers by the end of the study. The largest crab $(\mathrm{CL}=55 \mathrm{~mm})$ was seen in September 1996 and this may well 


\section{TABLE I}

Numbers of juveniles of Ozius truncatus H. Milne Edwards $(\mathrm{CL}<15 \mathrm{~mm})$ males and females in monthly samples. Mean size and standard error of the mean are given in mm carapace length. Numbers of females include ovigerous crabs; ${ }^{*}$, significant difference from expected $1: 1$ ratio at 0.05 confidence level

\begin{tabular}{|c|c|c|c|c|c|c|}
\hline Time & $\begin{array}{l}\text { No. of juveniles } \\
\text { (Average } \\
\text { size } \pm \text { SE) }\end{array}$ & $\begin{array}{l}\text { No. of males } \\
\quad(\text { Average } \\
\text { size } \pm \mathrm{SE})\end{array}$ & $\begin{array}{l}\text { No. of females } \\
\quad \text { (Average } \\
\text { size } \pm \text { SE) }\end{array}$ & $\begin{array}{c}\text { No. of } \\
\text { ovigerous } \\
\text { females }\end{array}$ & $\begin{array}{l}\text { Male } \\
\text { female } \\
\text { ratio }\end{array}$ & $\chi^{2}$ \\
\hline May 1996 & $\begin{array}{c}3 \\
(13.7 \pm 0.88)\end{array}$ & $\begin{array}{c}20 \\
(25.8 \pm 0.81)\end{array}$ & $\begin{array}{c}21 \\
(30.3 \pm 1.22)\end{array}$ & 0 & 0.95 & 0.02 \\
\hline June 1996 & $\begin{array}{c}1 \\
(12)\end{array}$ & $\begin{array}{c}11 \\
(28.5 \pm 1.34)\end{array}$ & $\begin{array}{c}8 \\
(31.75 \pm 1.6)\end{array}$ & 0 & 1.37 & 0.47 \\
\hline July 1996 & 0 & $\begin{array}{c}11 \\
(29 \pm 1.89)\end{array}$ & $\begin{array}{c}10 \\
(27.7 \pm 2.3)\end{array}$ & 0 & 1.1 & 0.05 \\
\hline Aug. 1996 & 0 & $\begin{array}{c}36 \\
(30.39 \pm 0.9)\end{array}$ & $\begin{array}{c}28 \\
(29.9 \pm 1.1)\end{array}$ & 0 & 1.28 & 0.89 \\
\hline Sept. 1996 & 0 & $\begin{array}{c}33 \\
(27.5 \pm 0.84)\end{array}$ & $\begin{array}{c}30 \\
(29.8 \pm 0.78)\end{array}$ & 0 & 1.1 & 0.14 \\
\hline Oct. 1996 & $\begin{array}{c}1 \\
(12)\end{array}$ & $\begin{array}{c}26 \\
(28.96 \pm 0.8)\end{array}$ & $\begin{array}{c}48 \\
(29.9 \pm 0.8)\end{array}$ & $\begin{array}{c}21 \\
(29.5 \pm 0.8)\end{array}$ & 0.54 & $6.54^{*}$ \\
\hline Nov. 1996 & $\begin{array}{c}1 \\
(8)\end{array}$ & $\begin{array}{c}48 \\
(27.5 \pm 0.68)\end{array}$ & $\begin{array}{c}48 \\
(29.1 \pm 0.75)\end{array}$ & $\begin{array}{c}32 \\
(28.0 \pm 0.7)\end{array}$ & 1 & 0 \\
\hline Dec. 1996 & $\begin{array}{c}1 \\
(9)\end{array}$ & $\begin{array}{c}41 \\
(27.8 \pm 0.82)\end{array}$ & $\begin{array}{c}35 \\
(27.5 \pm 0.9)\end{array}$ & $\begin{array}{c}13 \\
(26.5 \pm 0.8)\end{array}$ & 1.17 & 0.47 \\
\hline Jan. 1997 & $\begin{array}{c}16 \\
(10.5 \pm 0.35)\end{array}$ & $\begin{array}{c}60 \\
(28.1 \pm 0.53)\end{array}$ & $\begin{array}{c}56 \\
(29.1 \pm 0.7)\end{array}$ & $\begin{array}{c}6 \\
(32.7 \pm 0.9)\end{array}$ & 1.07 & 0.14 \\
\hline Feb. 1997 & $\begin{array}{c}19 \\
(10.3 \pm 0.59)\end{array}$ & $\begin{array}{c}54 \\
(28.1 \pm 0.72)\end{array}$ & $\begin{array}{c}60 \\
(29.4 \pm 0.65)\end{array}$ & $\begin{array}{c}2 \\
(32.0)\end{array}$ & 0.9 & 0.32 \\
\hline Mar. 1997 & $\begin{array}{c}45 \\
(11.3 \pm 0.35)\end{array}$ & $\begin{array}{c}53 \\
(28.7 \pm 0.86)\end{array}$ & $\begin{array}{c}46 \\
(29 \pm 0.7)\end{array}$ & 0 & 1.15 & 0.50 \\
\hline Apr. 1997 & $\begin{array}{c}37 \\
(11.3 \pm 0.38)\end{array}$ & $\begin{array}{c}25 \\
(29.5 \pm 1.26)\end{array}$ & $\begin{array}{c}51 \\
(30.9 \pm 0.9)\end{array}$ & 0 & 0.49 & $8.9^{*}$ \\
\hline May 1997 & $\begin{array}{c}25 \\
(11.2 \pm 0.31)\end{array}$ & $\begin{array}{c}37 \\
(25.9 \pm 0.92)\end{array}$ & $\begin{array}{c}40 \\
(31.58 \pm 1.2)\end{array}$ & 0 & 0.925 & 0.12 \\
\hline June 1997 & $\begin{array}{c}19 \\
(12.6 \pm 0.49)\end{array}$ & $\begin{array}{c}30 \\
(28.1 \pm 0.97)\end{array}$ & $\begin{array}{c}36 \\
(28.1 \pm 1.2)\end{array}$ & 0 & 0.83 & 0.55 \\
\hline July 1997 & $\begin{array}{c}12 \\
(9.7 \pm 0.54)\end{array}$ & $\begin{array}{c}22 \\
(26.7 \pm 1.83)\end{array}$ & $\begin{array}{c}20 \\
(25.3 \pm 1.47)\end{array}$ & 0 & 1.1 & \\
\hline Aug. 1997 & $\begin{array}{c}9 \\
(10.1 .1 \pm 0.8)\end{array}$ & $\begin{array}{c}22 \\
(28.45 \pm 1.3)\end{array}$ & $\begin{array}{c}14 \\
(25.43 \pm 2.0)\end{array}$ & 0 & 1.57 & \\
\hline Sept. 1997 & $\begin{array}{c}18 \\
(10.2 \pm 0.5)\end{array}$ & $\begin{array}{c}29 \\
(28.72 \pm 1.1)\end{array}$ & $\begin{array}{c}47 \\
(29.1 \pm 0.99)\end{array}$ & 0 & 0.62 & \\
\hline Oct. 1997 & $\begin{array}{c}15 \\
(12.4 \pm 0.49)\end{array}$ & $\begin{array}{c}26 \\
(25.12 \pm 1.1)\end{array}$ & $\begin{array}{c}26 \\
(23.1 \pm 1.16)\end{array}$ & $\begin{array}{c}2 \\
(23.0)\end{array}$ & 1.0 & \\
\hline Nov. 1997 & $\begin{array}{c}18 \\
(9.1 \pm 0.43)\end{array}$ & $\begin{array}{c}38 \\
(28.24 \pm 1.1)\end{array}$ & $\begin{array}{c}38 \\
(27.1 \pm 1.08)\end{array}$ & $\begin{array}{c}29 \\
(29.8 \pm 0.9)\end{array}$ & 1.0 & \\
\hline
\end{tabular}


TABLE I

(Continued)

\begin{tabular}{|c|c|c|c|c|c|c|}
\hline Time & $\begin{array}{l}\text { No. of juveniles } \\
\text { (Average } \\
\text { size } \pm \text { SE) }\end{array}$ & $\begin{array}{c}\text { No. of males } \\
(\text { Average } \\
\text { size } \pm \text { SE) }\end{array}$ & $\begin{array}{l}\text { No. of females } \\
\text { (Average } \\
\text { size } \pm \text { SE) }\end{array}$ & $\begin{array}{l}\text { No. of } \\
\text { ovigerous } \\
\text { females }\end{array}$ & $\begin{array}{l}\text { Male } \\
\text { female } \\
\text { ratio }\end{array}$ & $\chi^{2}$ \\
\hline Dec. 1997 & $\begin{array}{c}17 \\
(10.5 \pm 0.34)\end{array}$ & $\begin{array}{c}49 \\
(26.6 \pm 1.06)\end{array}$ & $\begin{array}{c}60 \\
(28.4 \pm 0.85)\end{array}$ & $\begin{array}{c}16 \\
(31.7 \pm 0.7)\end{array}$ & 0.82 & \\
\hline Jan. 1998 & $\begin{array}{c}15 \\
(13.2 \pm 0.34)\end{array}$ & $\begin{array}{c}76 \\
(25.6 \pm 0.72)\end{array}$ & $\begin{array}{c}76 \\
(27.5 \pm 0.78)\end{array}$ & $\begin{array}{c}33 \\
(31.8 \pm 0.7)\end{array}$ & 1.0 & \\
\hline Feb. 1998 & $\begin{array}{c}10 \\
(12.9 \pm 0.4)\end{array}$ & $\begin{array}{c}42 \\
(24.9 \pm 1.12)\end{array}$ & $\begin{array}{c}49 \\
(28.5 \pm 1.08)\end{array}$ & $\begin{array}{c}3 \\
(37.7)\end{array}$ & 0.86 & \\
\hline Mar. 1998 & $\begin{array}{c}3 \\
(13.1 \pm 0.34)\end{array}$ & $\begin{array}{c}37 \\
(22.54 \pm 0.9)\end{array}$ & $\begin{array}{c}31 \\
(25.32 \pm 1.4)\end{array}$ & 0 & 1.19 & \\
\hline Apr. 1998 & $\begin{array}{c}4 \\
(13.5 \pm 0.59)\end{array}$ & $\begin{array}{c}41 \\
(24.34 \pm 1.1)\end{array}$ & $\begin{array}{c}32 \\
(26.5 \pm 1.32)\end{array}$ & 0 & 1.28 & \\
\hline May 1998 & $\begin{array}{c}3 \\
(13.7 \pm 0.58)\end{array}$ & $\begin{array}{c}35 \\
(23.5 \pm 0.95)\end{array}$ & $\begin{array}{c}24 \\
(24.42 \pm 1.1)\end{array}$ & 0 & 1.46 & \\
\hline June 1998 & $\begin{array}{c}1 \\
(14)\end{array}$ & $\begin{array}{c}38 \\
(23.68 \pm 0.9)\end{array}$ & $\begin{array}{c}35 \\
(27.88 \pm 1.3)\end{array}$ & 0 & 1.1 & \\
\hline July 1998 & $\begin{array}{c}2 \\
(14.0)\end{array}$ & $\begin{array}{c}37 \\
(25.54 \pm 1.1)\end{array}$ & $\begin{array}{c}44 \\
(26.98 \pm 0.9)\end{array}$ & 0 & 0.84 & \\
\hline
\end{tabular}

be a survivor from an even earlier cohort, perhaps 1994-95 or even 199394. This suggests that the life span of these crabs is of at least 3 years. The modal CL of the $1+, 2+$ and $3+$ cohorts is approximately $15 \mathrm{~mm}, 25 \mathrm{~mm}$, and $35 \mathrm{~mm}$. It is possible to follow the growth of the 1996-97 cohort recruited around December 1996. This group first becomes clearly evident amongst the rocks of Echinoderm Reef from January 1997, when CL was around $10 \mathrm{~mm}$, and can be traced through to February 1998 when most of them have joined the $\mathrm{CL}>15 \mathrm{~mm}$ crabs. Overall the mean male $\mathrm{CL}=27.0 \mathrm{~mm}$ and female $\mathrm{CL}=28.1 \mathrm{~mm}$.

Ovigerous females were recorded from October 1996 to February 1997 and again during the same months in the following summer (fig. 4). Their size ranged from 20 to $47 \mathrm{~mm} \mathrm{CL}$ with mean size tending to increase towards the end of the egg-bearing season (see table I). Peak numbers of ovigerous females occurred during the November-January period. These data suggest that upon reaching $20 \mathrm{~mm} \mathrm{CL}$, females produce a single brood of eggs and that egg and larval development take about 3 months (approx. $2+1$ months, respectively). While it can be argued that significant cohorts entered the population in the summers of 1995-96 and 1996-97, there does not appear to have been any significant recruitment in the summer of 1997-98. There was no $10 \mathrm{~mm}$ 


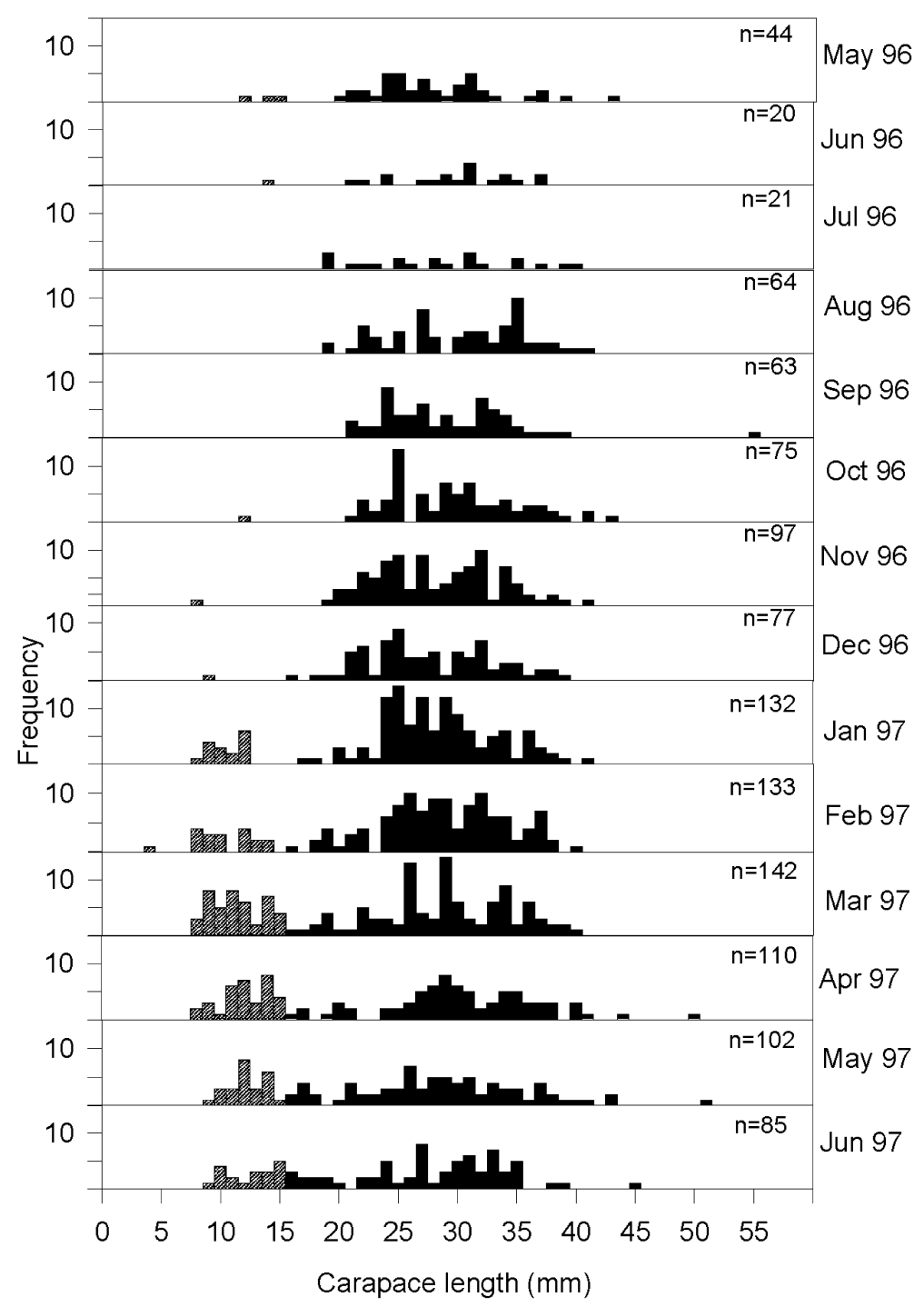

Fig. 2. Monthly population structure of Ozius truncatus H. Milne Edwards, 1834, males and females combined, from May 1996 to June 1997. Sample sizes shown in right-hand corner of each monthly histogram. Crabs greater than $15 \mathrm{~mm}$ carapace length shown as solid bars; smaller crabs shown as cross-hatched bars.

CL group in January 1998 similar to that seen in January 1997. Females produce their first clutch of eggs in the summer following their recruitment (age of approximately 1 year) and then annually for 2 to 3 further years, should they survive, giving a maximum of 3 to 4 annual broods during their lifetime. Recruitment to the shore population occurs from December to April. 


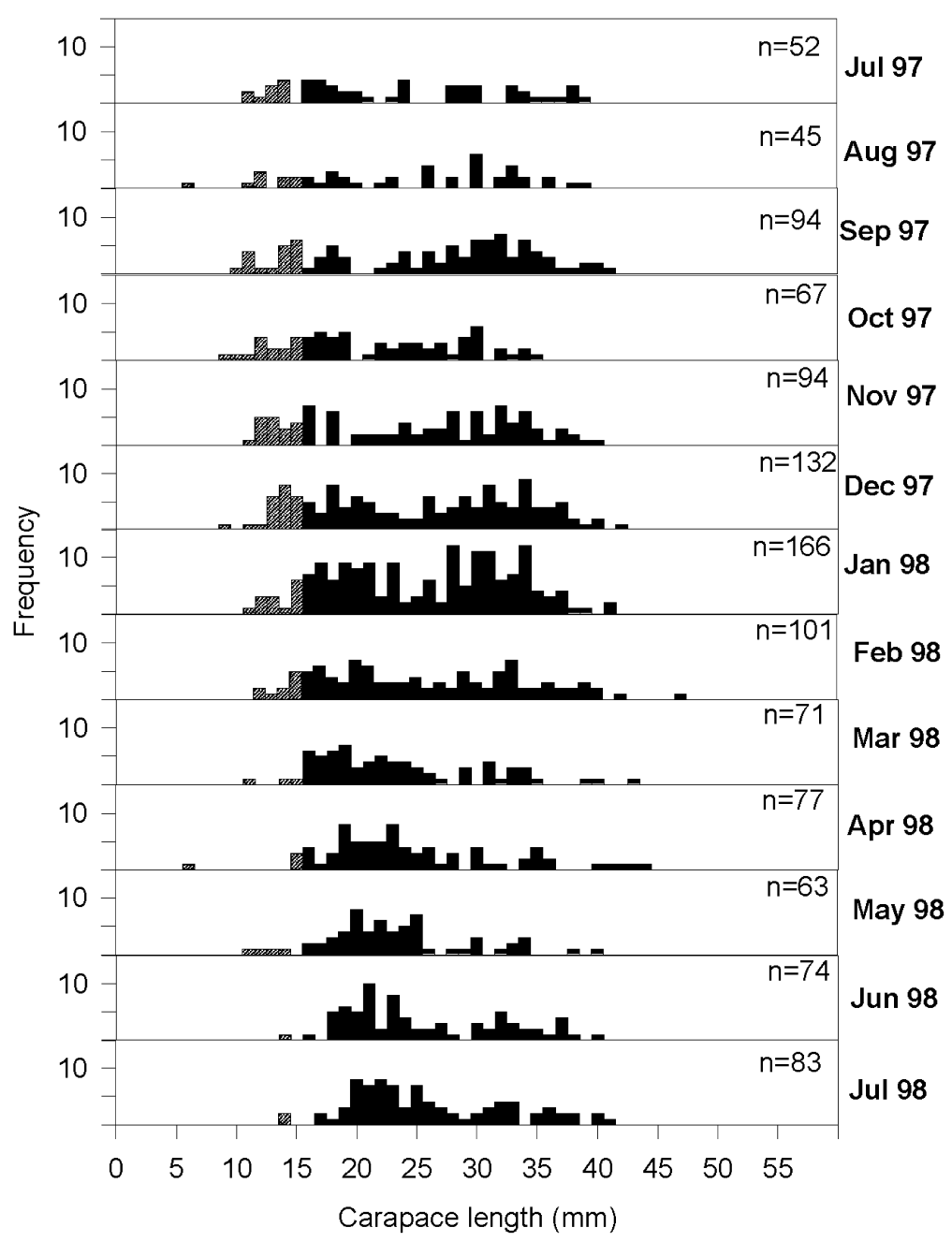

Fig. 3. Combined population structure of Ozius truncatus H. Milne Edwards, 1834, males and females combined, from July 1997 to July 1998. Sample sizes shown in right-hand corner of each monthly histogram. Crabs greater than $15 \mathrm{~mm}$ carapace length shown as solid bars; smaller crabs shown as cross-hatched bars.

The smallest crab found during sampling was $4 \mathrm{~mm}$, observed in February 1997.

The sex ratio of Ozius truncatus throughout the sampling period was approximately 1 : 1, with significant deviations only in October 1996 and April 1997 when females were approximately twice as common as males, and August 1997 and May 1998 when males out-numbered females (table I). Overall 1013 (51.7\%) crabs were female while 948 (48.3\%) were male. In 
most months females were larger than males: mean CL of females $=28.1 \mathrm{~mm}$ and mean $\mathrm{CL}=26.9 \mathrm{~mm}$ for males, but there was no seasonal pattern of $\mathrm{CL}$ differences.

During the 27-month study, the population size reached a peak of 166 in summer (January) and a minimum of 45 in late winter (August) (fig. 4). The pattern of seasonal fluctuations was remarkably similar between 1996 to 1998. The seasonal change is a reflection of summer recruitment by juveniles and winter mortality of larger crabs. The stable pattern between years is a reflection of the lack of physical disturbance on this relatively sheltered shore. Mean population size between August 1996 to July 1998 was 91.9 crabs $(\mathrm{SE}=6.3)$. The sampling methods used in this study do not allow us to transform number of crabs counted to density estimates, because we do not know how much of the area searched was habitable by $O$. truncatus. However, in April 1996 when areas $\mathrm{A}, \mathrm{C}, \mathrm{J}$, and $\mathrm{K}$ were quadrat sampled it was found that the mean density was $0.6 \mathrm{crabs} \mathrm{m}^{-2}$. During the following months, total crab numbers increased so that by the summer of $1996 / 97$ the density had risen to 2.16 crabs $\mathrm{m}^{-2}$. The actual density during the year will closely mirror the pattern seen in fig. 4.

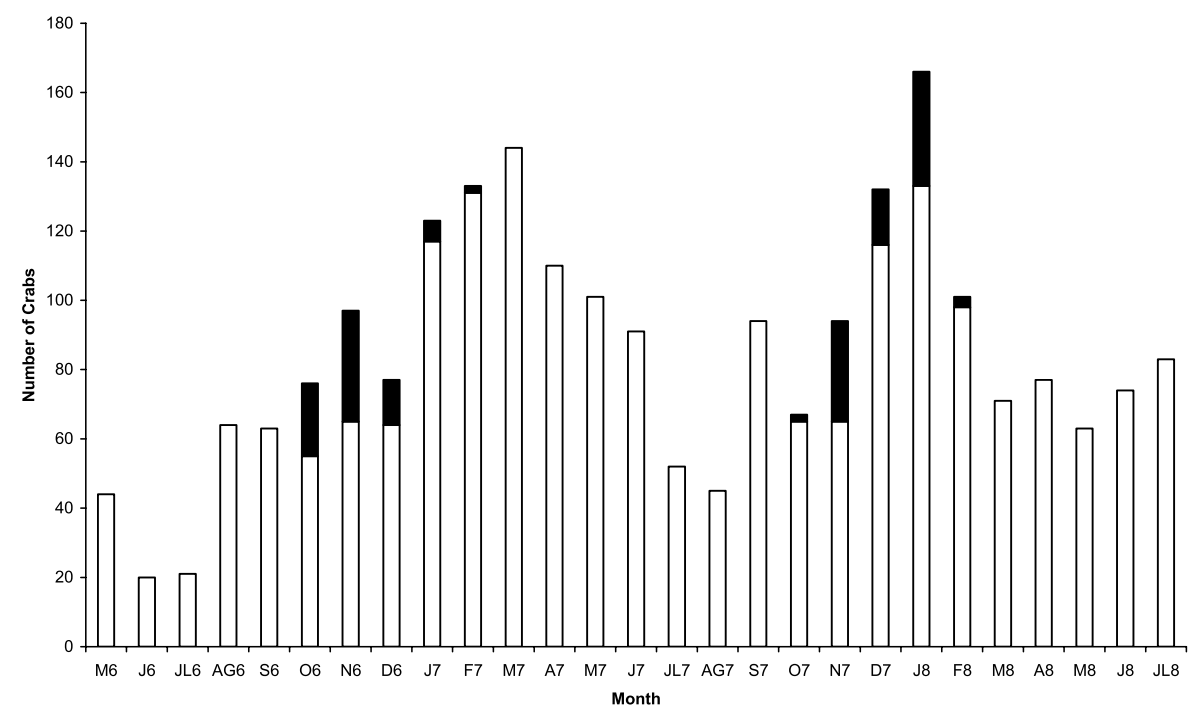

Fig. 4. Total population size of Ozius truncatus H. Milne Edwards, 1834 for clumps A-O from May 1996-July 1998. Ovigerous female numbers are shown by a filled bar. The first 3 months do not include clumps B, D, E, F, G, H, I, L, M, N, and O. The complete data set for all 15 clumps is from August 1996 to July 1998. 


\section{Variation in crab numbers in each clump}

Most specimens of $O$. truncatus are solitary, each found under a particular stone. Aggressive behaviour can be high when crabs have nowhere to hide (Sivaguru \& McLay, in prep.). Thus the maximum number of crabs in each area is set by the numbers of stones that provide habitable hiding spaces. Since this remains fairly constant over time one would expect the number of crabs in each clump to remain roughly the same, as long as the area is saturated with crabs. Fig. 5 shows the variation in numbers during the period May 1996 to June 1997. The total number of crabs recorded at each site over the 11-14 month period ranged from 10 (clump F; see fig. 1b) to 215 (clump A), mean = 77.2 $( \pm 15.0)$. For most of the less favoured sites (mean number of crabs per month $<5$ ) the variance/mean ratio was approximately 1.0, indicating that changes from month to month were random. For sites where more crabs were found (mean $>7$ ) the ratio ranged from 2.0-5.3, indicating more extreme changes. The large increases in numbers within some

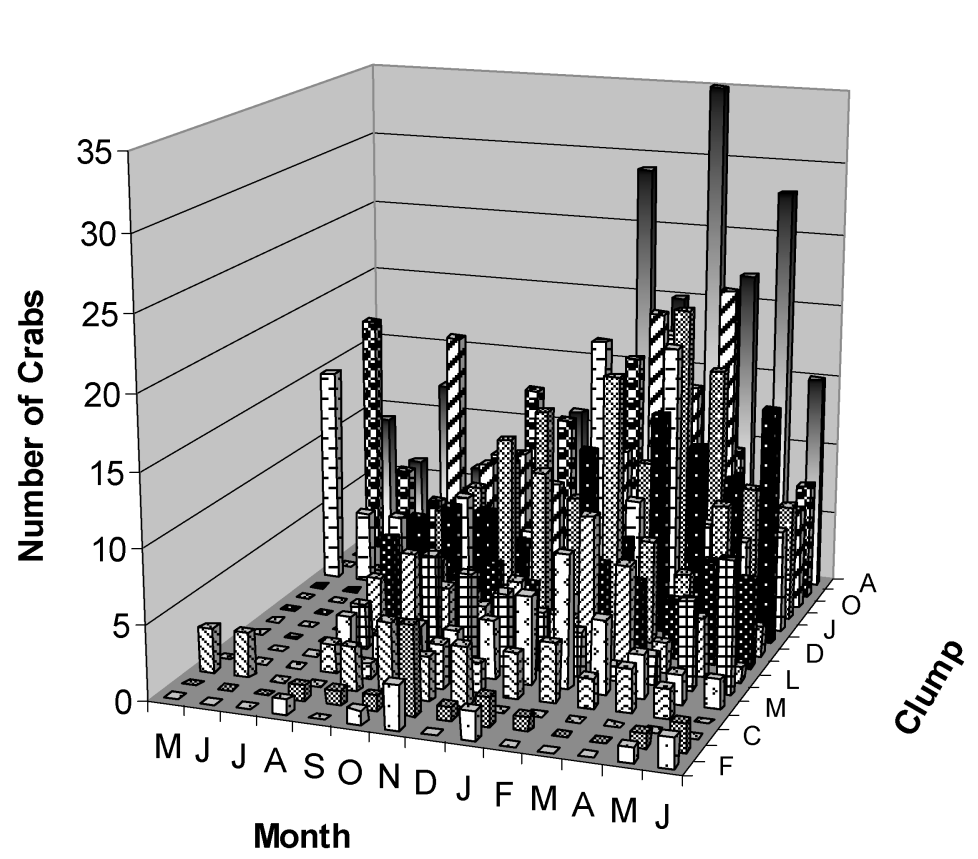

Fig. 5. Numbers of Ozius truncatus H. Milne Edwards, 1834 in each clump from May 1996 to June 1997. Note: prior to August 1996 clumps B, D, E, F, G, H, I, L, M, N, and O were not included. Data are complete for all 15 clumps for 11 months from August 1996 to June 1997. Clumps are arranged in abundance rank order from smallest (F) at the front to largest (A) at the back (see legend on graph). 
clumps (notably D, I, J, N, O, K, and A, see fig. 1b) was due to the recruitment of juveniles in the summer. Thus it seems that recruitment is greater in areas where there are already larger numbers of adults. These constituted about half of the sites. If these favoured sites are over-saturated, it does not seem that the overflow disperses (see below) to less favoured sites, which remain small sub-populations.

\section{Crab movements}

Specimens of Ozius truncatus were found underneath medium sized $(0.003$ to $0.15 \mathrm{~m}^{2}$ ) flat boulders of various shapes, surrounded by small pebbles or cobbles, and providing enough space to conceal the entire crab (see fig. 1c for example). Other species such as the filter-feeding half crab (Petrolisthes elongatus (H. Milne Edwards, 1837), Porcellanidae) and the detritus-feeding pebble crab (Heterozius rotundifrons A. Milne-Edwards, 1867; Belliidae) were also found in large numbers within the habitat sampled.

Most (93.5\%) tagged adult $O$. truncatus remained within the clumps where they were originally tagged, moving on average only $1.12 \mathrm{~m}$ (fig. 6). Only occasionally (six individuals) did they move outside the original clump to a distance of greater than $10 \mathrm{~m}$. Only one crab moved to an adjacent clump, moving a total distance of $8.2 \mathrm{~m}$. The average distance moved by all recovered crabs was $2.29 \mathrm{~m}$. These data suggest that the crabs mainly fed on prey species within the clumps in their immediate vicinity. Some of the tags were unreadable because they were damaged by the movement of crabs under boulders. This tagging method was not successful with juveniles because of frequent moulting, and so is more of an estimate of adult movements.

\section{DISCUSSION}

Ozius truncatus inhabits the upper middle intertidal levels on rocky shores living beneath larger cobbles and medium-sized boulders. Within these areas the crab has a patchy distribution. The population dynamics of $O$. truncatus at the Leigh Marine Reserve provided evidence of at least two cohorts that were recruited in the summers of 1996-97 and 1995-96 and possibly remnants of the 1995-1995 cohort. The progression of these cohorts through the population suggested that crabs reach CL $\sim 15 \mathrm{~mm}$ by age $1+\mathrm{yr}, \sim 25 \mathrm{~mm}$ by age $2+$ and $\sim 35 \mathrm{~mm}$ by age $3+$. Males and females grow to a similar maximum size (57 $\mathrm{mm}$ and $55 \mathrm{~mm} \mathrm{CL}$, respectively; see McLay, 1988) and the sex ratio at 


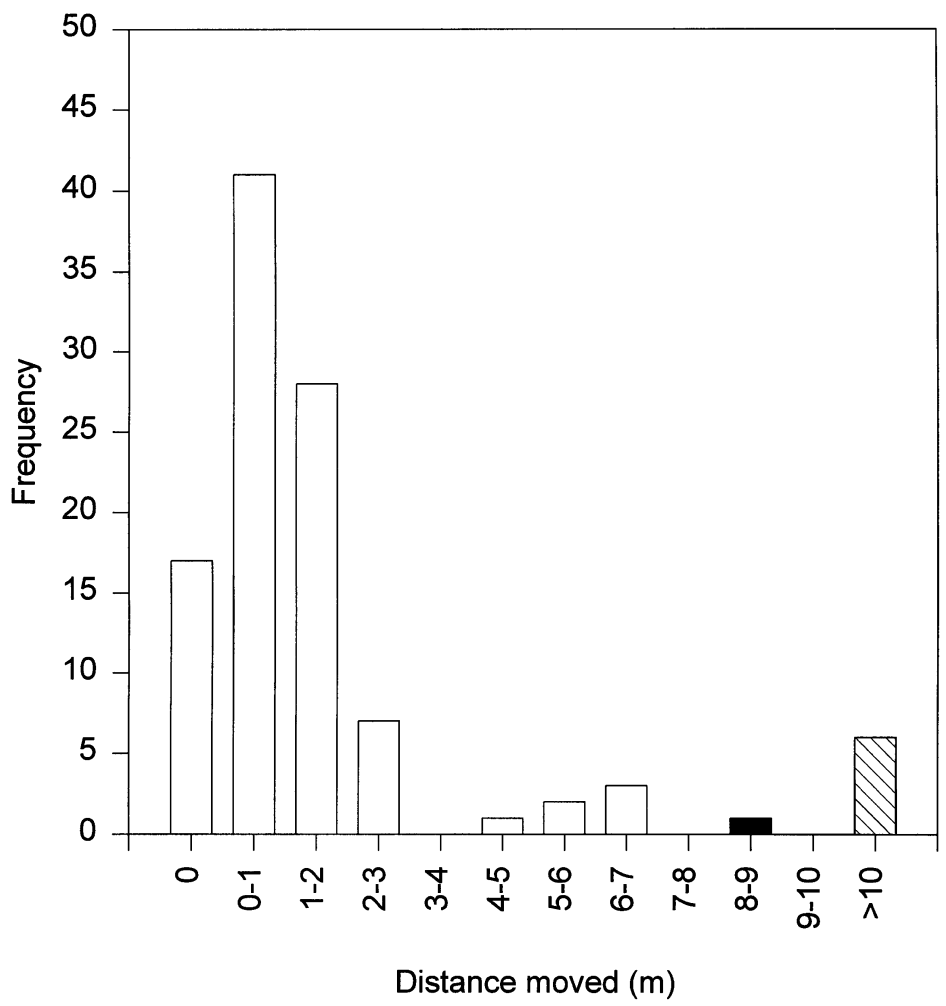

Fig. 6. Frequency distribution of the movements of tagged Ozius truncatus H. Milne Edwards, 1834 on Echinoderm Reef, New Zealand. Movements are pooled over the May-December 1996 period. Movements of less than $7 \mathrm{~m}$ (empty bars) were all within a clump; the single move of $8 \mathrm{~m}$ (filled bar) was between adjacent clumps (I and J); moves greater than $10 \mathrm{~m}$ (cross-hatched bar) were among widely-spaced clumps.

this location does not differ from a $1: 1$ ratio. Females reach sexual maturity during their first year (min. CL for ovigerous crabs was $20 \mathrm{~mm}$ ) and if they survive to maximum age they could produce 3 or 4 annual broods. Ovigerous females were found in the population from October to February, similar to that reported by McLay (1988). During the breeding season the mean CL of ovigerous females tends to increase as larger females become ovigerous later in the summer. Eggs are brooded by females for approximately 2 months, with the planktonic phase lasting about 1 month, so that recruitment begins in December. Juvenile crabs may settle in crevices and other inaccessible areas so that the exact timing of recruitment is uncertain. We were not able to detect juveniles entering the population until they became $\sim 5-10 \mathrm{~mm} \mathrm{CL}$. There was no evidence that recruitment was successful during 1997-98 (see fig. 3). The O. truncatus population is nevertheless maintained by surviving adults. 
The distribution of tagged crabs on the shore demonstrated that $O$. truncatus adults are largely sedentary. They show a high level of site fidelity and were only rarely recorded outside the clump where they were originally tagged. The mean distance moved between monthly samples was only $2.3 \mathrm{~m}$. This implies that the predatory impact of these crabs should be quite localized, but it is possible that they may move further afield when covered by the tide, returning to their original site at low tide. Bertness \& Cunningham (1981) found that Ozius verrauxii Saussure, 1853 in the Bay of Panama forages in the splash zone during both day and night time low tides. They suggest that close sympatry of the crabs and their gastropod prey may be enforced by fish predation. Unlike $O$. truncatus, $O$. verrauxii retires to a burrow, which may imply a high level of site fidelity. By contrast, Menippe mercenaria (Say, 1818) living in oyster clumps, made frequent short range $($ mean $=4.6 \mathrm{~m}$ ) movements and so only had a transient presence in a clump (Wilber, 1986).

Another predator in the Leigh Reserve that has been more intensively studied is the rock lobster, Jasus edwardsii (Hutton, 1875) (Palinuridae). It is a large predator that occupies the same subtidal sites for long periods, but ventures out of its shelter for local foraging on shellfish. Intensive studies of the movement of tagged lobsters show a high level of site fidelity. MacDiarmid et al. (1991) found that about $40 \%$ returned to the same shelter on consecutive days, and Kelly \& MacDiarmid (2003) found that 55\% of lobsters, tagged over two years, were found at the same site in 1996. In Tasmania, Barrett et al. (2009) recaptured $90 \%$ of tagged rock lobsters within $200 \mathrm{~m}$ of the release site on weekly to annual time scales. Jasus edwardsii forage chiefly at night when the median foraging range was only $24 \mathrm{~m}$ (MacDiarmid et al., 1991). Thus the impact on bivalve prey populations is restricted to near the daytime shelter.

Mobility and diet of crustacean predators may be related. Stachowicz \& Hay (1999) found that there was a relationship between diet and mobility of three seaweed eating crabs from North Carolina: the majid Mithraculus forceps A. Milne-Edwards, 1875 (as Mithrax) exhibited the lowest mobility, highest site fidelity, and least selective diet of the 3 species, whereas another majid Libinia dubia $\mathrm{H}$. Milne Edwards, 1834 was intermediate in both mobility and selectivity, and the panopeid Panopeus herbstii H. Milne Edwards, 1834 had the greatest mobility and narrowest diet. We might thus anticipate that $O$. truncatus could have a broad diet and eat any prey within the vicinity of its site. It is better to eat whatever is at hand rather than be exposed to danger and eaten.

Our estimates of the population densities of $O$. truncatus can only be approximate because we did not use random sampling. Had strict random 
sampling been employed, it is very unlikely that individuals would even have been detected as being present. If any shore sampling can be said to be random, it is only random within areas likely to yield positive samples (see McLay \& McQueen, 1995). In areas of Echinoderm Reef where it was known that there were relatively high numbers of crabs present (areas A, C, J, and K) we estimated that in April 1996 the mean density was $0.6 \mathrm{crabs} \mathrm{m}^{-2}$ and by the summer of $1996 / 97$ the density had risen to $2.16 \mathrm{crabs} \mathrm{m}^{-2}$. This should be regarded as the maximum density likely to be found at the site, and that the annual change in density should follow that of total numbers (fig. 4). The only other estimates of the density of $O$. truncatus were provided by Chilton \& Bull (1984) for a South Australia rocky platform. They used transect sampling methods, making direct comparison with our results difficult (only total numbers within $5 \mathrm{~m}$ intervals along transects are given), but based on their stated method we estimate that crab numbers ranged from 0.13 to $0.66 \mathrm{per} \mathrm{m}^{2}$. It thus seems that density on the South Australia rocky platform and the shore at Leigh is similar, but it is not clear whether we are comparing crabs of the same size range. Chilton \& Bull (1984) found evidence that the numbers of $O$. truncatus had a significant impact on the numbers of small gastropods (Nerita atramentosa Reeve, 1855, Bembicium nanum (Lamarck, 1822), and Diloma concamerata (Wood, 1828) (as Austrocochlea)) along the shore. Crabs selectively ate smaller snails.

Ozius truncatus is sparsely distributed on rocky shores, being restricted to patches of cobbles in mid to upper regions. Results suggest that $O$. truncatus is a slow-growing, long-lived, generally sedentary species that is unlikely to have more than a localized effect on shore communities, but as a result of selective grazing they could still be responsible for the size structure of their prey populations.

\section{ACKNOWLEDGEMENTS}

We would like to thank Bob Creese, Bob Lewis, and Richard Taylor for their guidance and help during this study, which was part of an M.Sc. thesis completed by the first author. Thanks are also due to all the technical staff at the Leigh Marine Laboratory. Assistance with field work was generously given by many contemporary graduate students. It is a privilege for both of us to acknowledge and recognize the important contribution that Daniele Guinot has made to knowledge and understanding of the Brachyura. Her influence will be enduring. 


\section{REFERENCES}

AYLING, A. M., 1978. Cape Rodney to Okakari Point Marine Reserve Survey. Leigh Laboratory Bulletin, 1: 1-98.

BARRETt, N., C. BusXton \& C. GARDNer, 2009. Rock lobster movement patterns and population structure within a Tasmanian Marine Protected Area inform fishery and conservation management. Marine and Freshwater Research, 60: 417-425.

Bertness, M. D. \& C. Cunningham, 1981. Crab shell-crushing predation and gastropod architectural defense. Journal of Experimental Marine Biology and Ecology, 50: 213-230.

Chilton, N. B. \& C. M. Bull, 1984. Influence of predation by a crab on the distribution of the size groups of three intertidal gastropods in Australia. Marine Biology, Berlin, 83: 163-169.

— — \& — , 1986. Size-related selection of two intertidal gastropods by the reef crab Ozius truncatus. Marine Biology, Berlin, 93: 475-480.

Creese, R. G., 1988. Ecology of molluscan grazers and their interactions with marine algae in north-eastern New Zealand: a review. New Zealand Journal of Marine and Freshwater Research, 22: 427-444.

Evans, J., 1992. Leigh climate report. Leigh Laboratory Bulletin, 27: 1-56.

Holling, C. S., 1966. The functional response of invertebrate predators to prey density. Memoirs of the Entomological Society of Canada, 48: 1-86.

Hughes, R. N., 1989. Foraging behaviour of a tropical crab: Ozius verreauxii. Proceedings of the Royal Society of London, (B) 237: 201-212.

- - 1993. Consumption of gastropods by the reef crab Ozius truncatus $\mathrm{H}$. Milne Edwards; the role of opportunistic foraging behaviour. In: F. E. WELLS, D. I. WALKER, H. KIRKMAN \& R. LEETHBridge (eds.), The marine flora and fauna of Rottnest Island, Western Australia: 443-453. (Western Australian Museum, Perth).

Kelly, S. \& A. B. MacDiarmid, 2003. Movement patterns of mature spiny lobsters, Jasus edwardsii, from a marine reserve. New Zealand Journal of Marine and Freshwater Research, 37: 149-158.

Kitching, J. A. \& J. LocKWood, 1974. Observations on shell form and its ecological significance in thaid gastropods of the genus Lepsiella in New Zealand. Marine Biology, Berlin, 28: 131-141.

LOWELL, R. B., 1986. Crab predation on limpets: predator behavior and defensive features of the shell morphology of the prey. Biological Bulletin, Woods Hole, 171: 577-596.

Lubchenco, J., B. A. Menge, S. D. Garrity, P. J. Lubchenco, L. R. Ashkenas, S. D. Gaines, R. Emlet, J. LuCAS \& S. Strauss, 1984. Structure, persistence, and role of consumers in a tropical rocky intertidal community (Taboguilla Island, Bay of Panama). Journal of Experimental Marine Biology and Ecology, 78: 23-73.

MacDiarmid, A. B., B. Hickey \& R. A. Mailer, 1991. Daily movement patterns of the spiny lobster Jasus edwardsii (Hutton) on a shallow reef in northern New Zealand. Journal of Experimental Marine Biology and Ecology, 147: 185-205.

MCLAY, C. L., 1988. Crabs of New Zealand. Leigh Laboratory Bulletin, 22: 1-463.

MCLAY, C. L. \& D. J. MCQUEEN, 1995. Intertidal zonation of Cyclograpsus lavauxi H. Milne Edwards, 1853 (Brachyura: Grapsidae) along the coast of the South Island of New Zealand. Crustacean Research, 24: 49-64.

Menge, B. A., 1983. Components of predation intensity in the low zone of the New England rocky intertidal region. Oecologia, 58: 141-155.

MiLnE EDWARDS, H., 1834-1837. Histoire naturelle des Crustacés comprenant l'anatomie, la physiologie et la classification de ces animaux. Paris, Librairie Encyclopédique de Roret, 1: i-xxxv, 1-468; 2: 1-531; Atlas, 1837: 1-32, pls. 1-42; 3, 1840: 1-638. 
SivagurU, K., 1997. The feeding ecology and behaviour of a predatory shore crab Ozius truncatus (Decapoda: Xanthidae): 1-145. (M.Sc. Thesis, University of Auckland).

Sivaguru, K. \& C. L. MCLAY, in prep. Predation of intertidal gastropods on Echinoderm Reef, Leigh Marine Reserve, New Zealand by Ozius truncatus H. Milne Edwards, 1834 (Brachyura: Oziidae).

Skilleter, G. A. \& D. T. Anderson, 1986. Functional morphology of the chelipeds, mouthparts and gastric mill of Ozius truncatus (Milne Edwards) (Xanthidae) and Leptograpsus variegatus (Fabricius) (Grapsidae) (Brachyura). Australian Journal of Marine \& Freshwater Research, 37: 67-79.

STACHOWICZ, J. J. \& M. E. HAY, 1999. Reduced mobility is associated with compensatory feeding and increased diet breadth of marine crabs. Marine Ecology Progress Series, 188: 169-178.

WEAR, R. G., 1968. Life-history studies on New Zealand Brachyura. 2. Family Xanthidae. Larvae of Heterozius rotundifrons A. Milne-Edwards, 1867, Ozius truncatus H. Milne Edwards, 1834, and Heteropanope (Pilumnopeus) serratifrons (Kinahan, 1856). New Zealand Journal of Marine and Freshwater Research, 2: 293-332.

Wear, R. G. \& D. R. Fielder, 1985. The Marine Fauna of New Zealand: Larvae of the Brachyura (Crustacea, Decapoda). New Zealand Oceanographic Institute Memoirs, 92: $1-90$.

WILBER, D. H., 1986. The distribution and daily movement of stone crabs (Menippe mercenaria) in an intertidal oyster habitat on the Northwest coast of Florida. Marine Behaviour and Physiology, 12: 279-291.

First received 17 June 2009.

Final version accepted 13 July 2009. 